\title{
Contribution to the identification of the species Myrcia hatschbachii D. Legrand (Myrtaceae): anatomical and histochemical analyses
}

\author{
Contribuição para a identificação da espécie Myrcia hatschbachii D. \\ Legrand (Myrtaceae): análises anatômicas e histoquímicas
}

\author{
Larissa Junqueira Gatto' ${ }^{(D)}$, Vanessa Barbosa Bobek'(D), Jane Manfron Budel"(iD, \\ Natasha Tiemi Fabri' ${ }^{(D}$, Josiane de Fatima Gaspari Dias'iD, \\ Obdulio Gomes Miguel'(D), Marilis Dallarmi Miguel'(D) \\ ' Federal University of Parana, Curitiba, PR, Brazil \\ "State University of Ponta Grossa, Ponta Grossa, PR, Brazil
}

\begin{abstract}
The genus Myrcia is used in folk medicine to treat diabetes. The plants used in folk medicine require morphological and anatomical references to attest to its authenticity. This is the first report of the microscopic study of Myrcia hatschbachii. In this sense, the aim of the present study was to describe the anatomical characteristics, in order to contribute to the species' identification. For anatomical and surface analyses free-hand sections were prepared and observed using optical microscopy, simultaneously some materials were processed and observed under scanning electron microscopy. In addition, histochemical tests were performed. The anatomical features described here correspond with previously reported features found in other species of the genus Myrcia. Furthermore, the following anatomical markers were observed in Myrcia hatschbachii: druses in the spongy parenchyma, concaveconvex midrib, heart-shaped petiole, oval-shaped stem, C-shaped vascular bundle in the midrib and open arc shape with invaginated ends in the petiole; phenolic compounds in the phloem and lignified cells in the pith. The results of anatomical and histochemical analyses provide micromorphological and microchemical features that can help in the taxonomy and proper identification of the species.
\end{abstract}

Keywords: Microscopy; Microchemistry; Morpho-anatomy; Myrtaceae; Scanning electron microscopy

\section{RESUMO}

O gênero Myrcia é usado na medicina popular para tratar a diabetes. As plantas utilizadas na medicina popular requerem referências morfológicas e anatômicas para atestar sua autenticidade. Este é o primeiro relato do estudo microscópico de Myrcia hatschbachii. Nesse sentido, o objetivo do presente 
estudo foi descrever as características anatômicas, a fim de contribuir para a identificação da espécie. Para as análises anatômicas e de superfície, cortes à mão livre foram preparados e observados em microscopia óptica, simultaneamente alguns materiais foram processados e observados em microscopia eletrônica de varredura. Além disso, foram realizados testes histoquímicos. As características anatômicas descritas aqui correspondem às características relatadas anteriormente encontradas em outras espécies do gênero Myrcia. Além disso, os seguintes marcadores anatômicos foram observados em Myrcia hatschbachii: drusas no parênquima esponjoso, nervura central côncava-convexa, pecíolo em forma de coração, caule com formato ovalado, feixe vascular em C na nervura central e forma de arco aberto com extremidades invaginadas no pecíolo; compostos fenólicos no floema e células lignificadas na medula. Os resultados das análises anatômicas e histoquímicas fornecem características micromorfológicas e microquímicas que podem auxiliar na taxonomia e identificação adequada das espécies.

Palavras-chave: Microscopia; Microquímica; Morfoanatomia; Myrtaceae; Microscopia eletrônica de varredura

\section{INTRODUCTION}

Myrcia DC. belongs to the subtribe Myrciinae O.Berg (sensu LUCAS et al., 2019) and to the tribe Myrteae (sensu WILSON et al., 2005). It is one of the largest genera of Myrtaceae, comprehending 780 Neotropical species (SANTOS et al., 2016). In Brazil 411 native species of Myrcia can be found, especially in Brazilian cerrado and Atlantic Forest (LUCAS et al., 2011; FLORA DO BRASIL, 2020). Several Myrcia species are called insulin plants, due to its folk use in the treatment of diabetes. This group of plants includes Myrcia punicifolia (Kunth) DC., Myrcia speciosa (Amsh.) Mc Vaugh, Myrcia amazonica DC., Myrcia citrifolia (Aubl.) Urb., Myrcia guianensis (Aubl.) DC., Myrcia multiflora (Lam.) DC., Myrcia salicifolia DC., Myrcia sylvatica (G. Mey) DC., Myrcia uniflora DC. (CASCAES et al., 2015). It is important to highlight that $M$. multiflora, known as "pedra-ume-caa", is found in the market sold in the form of tea or capsules to treat diabetes (BRITO; LANETTI, 1996). Additionally, species of Myrcia are traditionally used as astringents and diuretics and in the treatment of ulcers and hypertension (ALVES et al., 2016).

The plants used in folk medicine require morphological and anatomical references to attest for its authenticity, since the morphological similarity or use of such popular names can lead to improper use of certain plant drug. In this sense, the American species of Myrtaceae are similar in most of the morphological characters, making their identification and classification difficult. Thus, the 
anatomical aspects assist the correct diagnosis of plant species, even when they are outside the flowering or fruiting period (DONATO; MORRETES, 2011).

Myrcia hatschbachii D. Legrand is a native and endemic tree from the Southern states of Brazil and presents Atlantic Forest domain (BFG, 2018). A study with the species showed a high content of phenolic compounds and the characterization of ellagic acid and 3-o-methyl ellagic acid. In addition, the extract exhibited antioxidant properties, by the methods of DPPH, FRAP, and ABTS, and relevant antifungal activity against Candida albicans (GATTO et al., 2020). Considering the potential therapeutic use of the species (GATTO et al., 2020), the morphological similarities in the family (DONATO; MORRETES, 2011) and the absence of anatomical studies published in the literature, the aim of the present study was to carry out an anatomical and histochemical analyses in order to contribute to the identification of $M$. hatschbachii and assist further studies on the possible differentiation of this species from other species of the genus Myrcia, including the insulin plants group since the morphological characterization between them is similar.

\section{MATERIALS AND METHODS}

\subsection{Plant materials}

Aerial vegetative parts of $M$. hatschbachii were collected in autumn, at the Cifloma Capon, located at the Federal University of Parana; Curitiba, Brazil (coordinates $25^{\circ} 26^{\prime} \mathrm{S}, 49^{\circ} 14^{\prime} \mathrm{W}$ ). Species identification was done by a taxonomist, in comparison to specimen number 72379 held at the herbarium in the MBM. Access to the botanical material was approved and licensed by the Ministério do Meio Ambiente and registered under number 02001.001165/2013-47. 


\subsection{Light microscopy}

Fresh leaves and stems (secondary structure) were fixed in an FAA solution (JOHANSEN, 1940) and stored in 70\% ethanol (BERLYN; MIKSCHE, 1976). Semipermanent microscope slides were obtained through free-hand paradermal and cross sections (OLIVEIRA; AKISUE, 1997), then the sections were stained with Astra blue and basic fuchsine (O'BRIEN et al., 1964). The sections were then mounted on glass slides in a drop of 50\% glycerin (BERLYN; MIKSCHE, 1976).

For the preparation of permanent slides, some of the FAA-fixed specimens were washed in distilled water and then dehydrated using a series of ethanol solutions $(30,50,70,95$, and $100 \%)$ before passing through a graded series of xylene: ethanol solutions and then to $100 \%$ xylene. The specimens were then embedded in paraffin and transversely sectioned (7-9 $\mu \mathrm{m}$ thick) with a rotary microtome (Spencer 820). Paraffin from the sections was removed using xylene. The sections were then rehydrated, stained with astra blue/basic fuchsin (ROESER, 1972), and mounted in synthetic resin (Entellan $\left.{ }^{\circledR}\right)$.

For the analysis of the leaf epidermal features, the leaf specimens were cleared by submersion in a sodium hypochlorite solution for $24 \mathrm{~h}$. After the clarification, the material was rinsed with distilled water, a 5\% acetic acid solution, and then rinsed with distilled water before being stained with $1 \%$ safranine (FUCHS, 1963) and then the slides were mounted on glass slides in a drop of 50\% glycerin.

\subsection{Histochemical tests}

For the histochemical tests, freehand cross sections were made, after which the following reagents were used: potassium dichromate (GABE, 1968) and ferric chloride (JOHANSEN, 1940) solutions for the identification of phenolic compounds; Sudan III for lipids (SASS, 1951); phloroglucinol/HCl to distinguish lignified elements (FOSTER, 1949); 1\% iodine solution for starch (BERLYN; MIKSCHE, 1976); and sulfuric acid to determine the chemical composition of crystals (OLIVEIRA; AKISUE, 
1997). The photomicrographs were taken using a light microscope (Olympus CX 31) equipped with a C7070 digital camera.

\subsection{Scanning electron microscopy}

Newly collected samples of leaves and stems were dehydrated in a series of ethanol solutions of increasing concentrations and then dried in a Leica EM CPD300 critical point dryer (Leica Microsystems, Wetzlar, Germany). Afterwards, the dried samples were mounted on aluminum stubs using glued carbon ribbon and then coated with gold using a Quorum SC7620 sputter coater (Quorum technologies Ltd., Kent, UK). Electron micrographs were performed using a Tescan Mira3 field emission SEM in high vacuum mode with an accelerating voltage of $15 \mathrm{kV}$. This procedure was carried out at the multi-user laboratory (C-Labmu) in the State University of Ponta Grossa (UEPG).

\section{RESULTS}

In frontal view, the leaves of $M$. hatschbachii exhibit wavy anticlinal epidermal cell walls (Fig. 1b, c) and striated cuticle on both sides (Fig. 1d, e). The leaves are hypostomatic, and the stomata are paracytic (Fig. 1c). In cross-section, the epidermis is one-layered with cells more elongated in the anticlinal direction (Figs. 1f, 2a). The cuticle is thin on both surfaces and it reacts positively to Sudan III. Unicellular non-glandular trichomes can be observed (Fig. 2d). 
Figure 1 - Morpho-anatomy of leaves of Myrcia hatschbachii

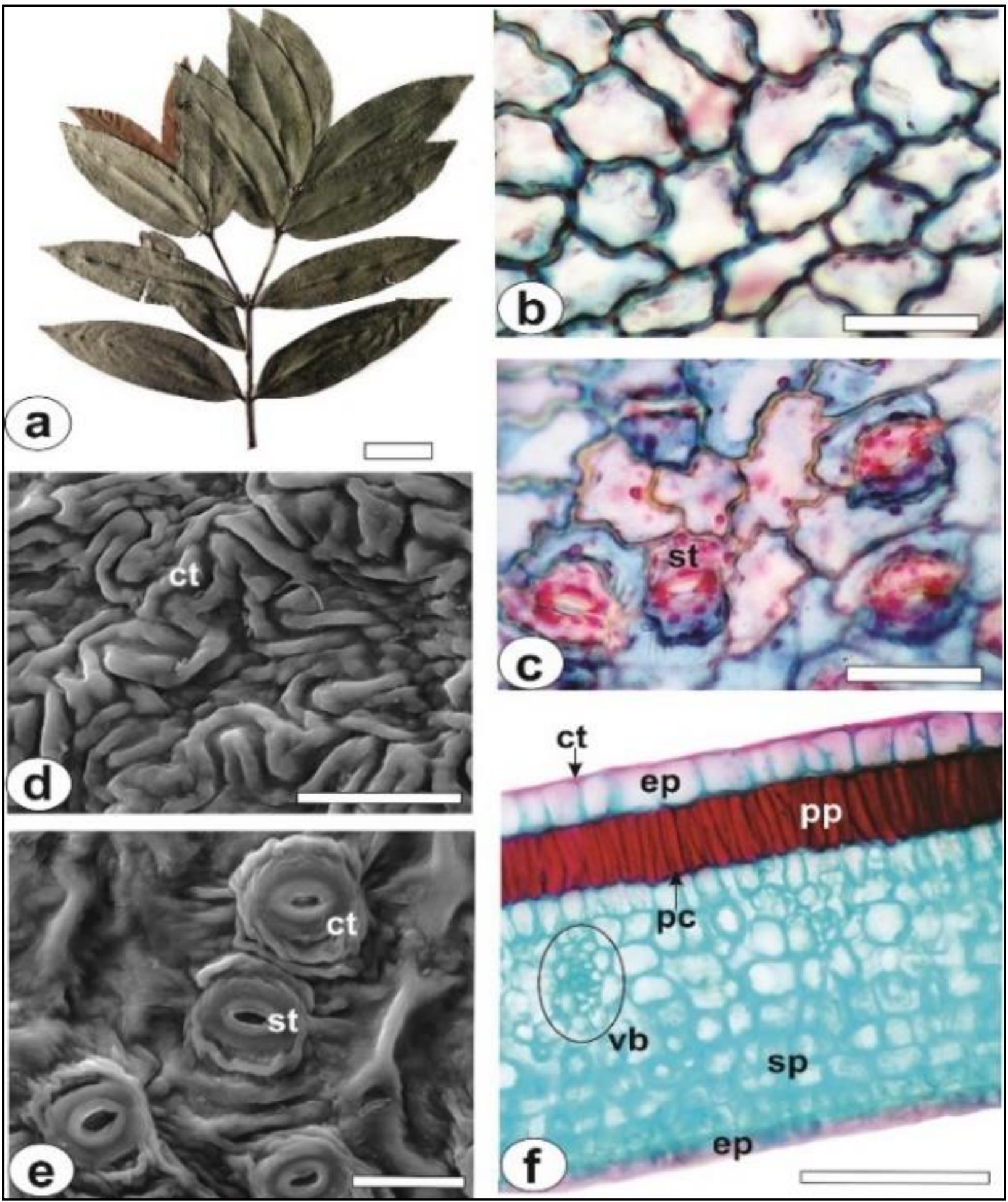

Source: Authors (2018)

In where: [b, c, and f: light microscopy; d-e: SEM]. (a) A shoot with leaves. (b-e) Leaf epidermis in surface view (b: adaxial side, showing the wavy anticlinal epidermal cell walls; $c$ : abaxial side, hypostomatic leaves; d: adaxial side, evidencing the striated cuticle; e: abaxial side, evidencing the striated cuticle). (f) Transverse sections of the leaf blade. [ct, cuticle; ep, epidermis; pc, phenolic compounds; pp, palisade parenchyma; sp, spongy parenchyma; st, stomata; vb, vascular bundle]. Scale bar: $a=2 \mathrm{~cm} ; f=50 \mu \mathrm{m} ; \mathrm{d}$, $\mathrm{e}=20 \mu \mathrm{m} ; \mathrm{b}-\mathrm{c}=25 \mu \mathrm{m}$. 
The mesophyll of leaves is dorsiventral, formed by a layer of palisade parenchyma (Figs. 1f, 2a) and approximately eight layers of spongy parenchyma. The cells of the palisade parenchyma have a high content of phenolic compounds, which reacted positively with the ferric chloride solution in the histochemical test (Fig. 2a, f). Minor collateral vascular bundles were located in the spongy parenchyma and were surrounded by a parenchymatic sheath (Fig. 1f). Several calcium oxalate druses were also found in the spongy parenchyma (Fig. 2a, b). The midrib has a concave-convex shape, with a prominent concavity on the adaxial side (Fig. 2c, f).

In the midrib region, the epidermis of leaves exhibits similar characteristics previously described for the lamina, except for being more densely covered by nonglandular trichomes. Beneath the epidermis, there are some layers of angular collenchyma on both sides. The vascular system is bicollateral (Fig. 2c, f, g, h), with a single C-shaped vascular bundle with the opening facing the adaxial side. The vascular system is surrounded by a continuous sclerenchymatic sheath (Fig. 2c, e), which reacts positively with phloroglucinol/ $/ \mathrm{HCl}$ in the histochemical test. Several phenolic compounds are present in the phloem (Fig. 2e, h), and they react with ferric chloride (Fig. 2f) and potassium dichromate (Fig. 2g). The ground parenchyma contains secretory cavities (Fig. 2f), starch grains, and calcium oxalate druses (Fig. $2 b)$. 
Figure 2 - Anatomy of leaves of Myrcia hatschbachii

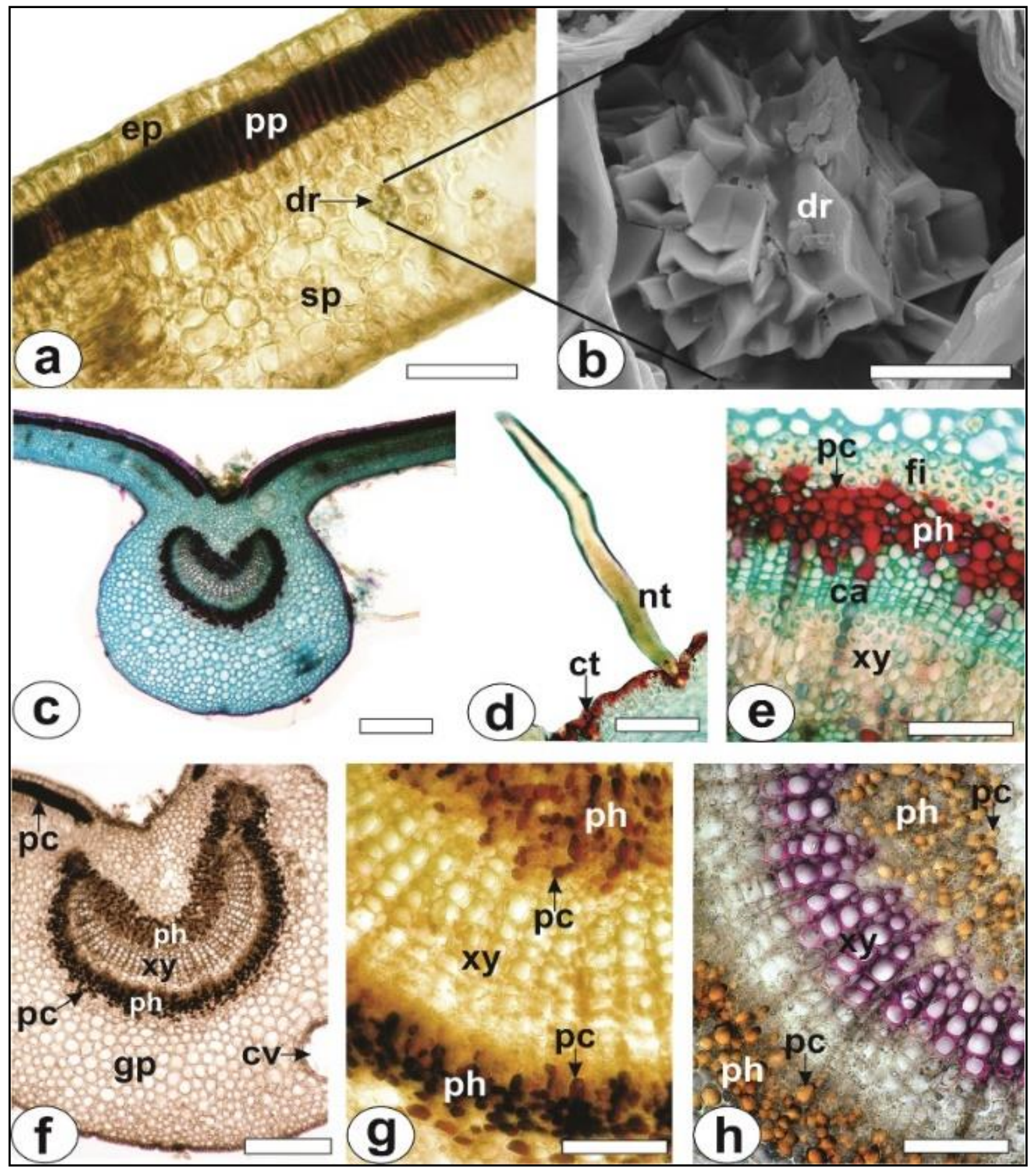

Source: Authors (2018)

In where: [a, c-h: light microscopy; b: SEM]. Transverse sections of the leaf blade $(a, b)$ and the midrib (ch). Phenolic compounds in reaction with ferric chloride $(a, f)$ and potassium dichromate $(g)$; Cuticle in reaction with Sudan III (d); Xylem in reaction with phloroglucinol/HCl (f). [ca, cambia; ct, cuticle; dr, druse; ep, epidermis; fi, fiber; gp, ground parenchyma; nt, non-glandular trichome; $p c$, phenolic compounds; ph, phloem; pp, palisade parenchyma; sp, spongy parenchyma; st, stomata; vb, vascular bundle; $x y, x y l e m]$. Scale bar: $a=50 \mu \mathrm{m} ; c=500 \mu \mathrm{m} ; \mathrm{f}=200 \mu \mathrm{m} ; \mathrm{a}, \mathrm{d}, \mathrm{e}=50 \mu \mathrm{m} ; \mathrm{b}=10 \mu \mathrm{m}$. 
The petiole, in cross section, is heart shaped. A large amount of non-glandular trichomes covers the single-layered epidermis (Fig. 3a, b). The cuticle and the content of the secretory cavities (Fig. 3c) reacted with Sudan III (Fig. 3b). Several druses (Fig. 3c) and starch grains were scattered in the ground parenchyma. These grains reacted with iodine solution (Fig. 3e).

The vascular system of petiole consists of a bicollateral vascular bundle in an open arch with invaginated ends (Fig. 3a, d). The reaction of the xylem with phloroglucinol/HCl is highlighted in Figure 3d. Phenolic compounds can be observed in the phloem, evidenced by the positive reaction with ferric chloride in the histochemical test (Fig. 3f).

Figure 3 - Anatomy of the petiole of Myrcia hatschbachii

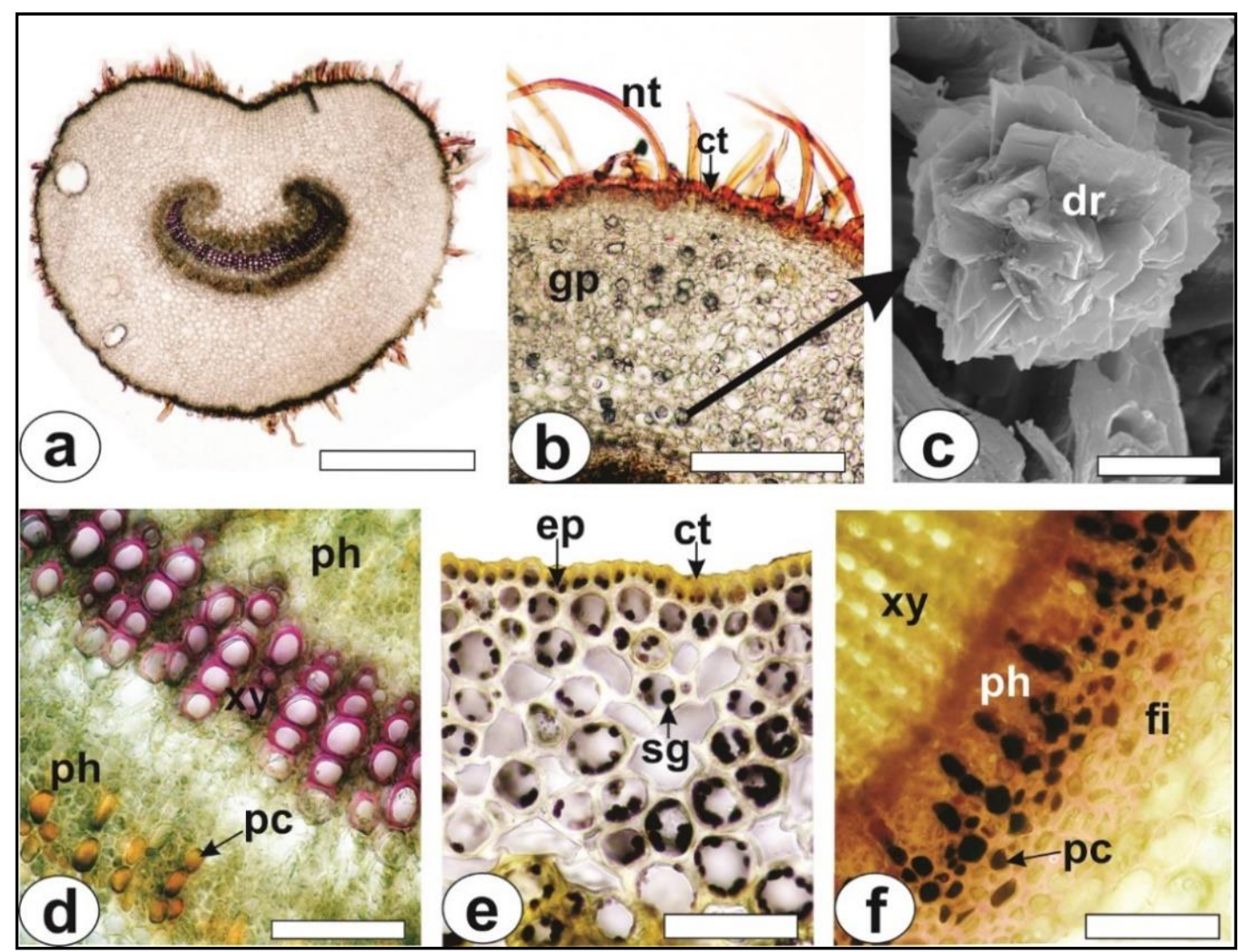

Source: Authors (2018)

In where: [a, b, d-f: light microscopy; c: SEM]. Cross section. Petiole is heart shaped (a); Cuticle in reaction with Sudan III (b); Druses in the ground parenchyma (c); Xylem in reaction with phloroglucinol/HCl (d); Starch grains in reaction with iodine solution (e); Phenolic compounds in reaction with ferric chloride (f). [ct, cuticle; dr, druse; ep, epidermis; fi, fiber; gp, ground parenchyma; nt, non-glandular trichome; $p c$, phenolic compound; ph, phloem; st, stomata; $x y, x y l e m]$. Scale bar: $a=500 \mu \mathrm{m} ; b=300 \mu \mathrm{m} ; \mathrm{d}-\mathrm{f}=50 \mu \mathrm{m}$; $\mathrm{c}=5 \mu \mathrm{m}$. 
The stem of M. hatschbachii is oval in cross-section (Fig. 4a, b). The epidermis is uniserial and covered by a striated cuticle that reacts positively with Sudan III (Fig. 4c). Unicellular, non-glandular trichomes are frequently present (Fig. 4b).

Secretory cavities of stem are present in the cortex (Fig. 4a, c). The lipophilic content of the cavities reacted with Sudam III in the histochemical tests. The vascular system is bicollateral, surrounded by a discontinuous sclerenchymatic sheath that reacts positively in the hydrochloric phloroglucinol/HCl test (Fig. 4d). Phenolic compounds are present in the phloem (Fig. 4f), and lignified cells in the pith (Fig. 4e), as well as numerous calcium oxalate druses (Fig. 4g). 


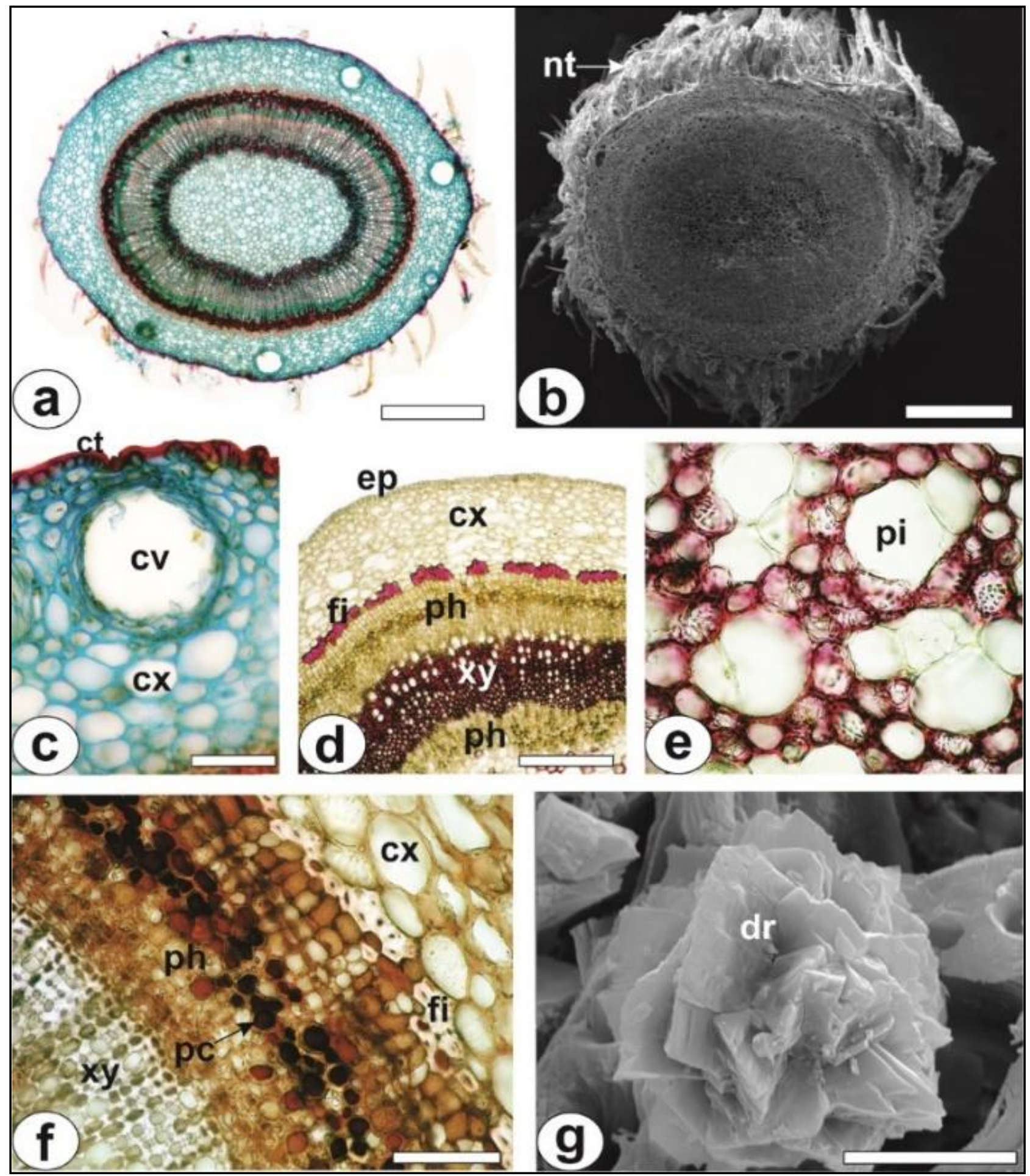

Source: authors, 2018

In where: [a, c-f: light microscopy; b, g: SEM]. Cross section. Stem is oval and non-glandular trichomes are present $(a, b)$; Cuticle in reaction with Sudan III (c); Fibers, xylem (d) and cells in the pith (e) in reaction with phloroglucinol/HCl; Phenolic compounds in reaction with ferric chloride $(\mathrm{f})$; Calcium oxalate druses (g). [ct, cuticle; cv, secretory cavities; cx, cortex; dr, druse; ep, epidermis; fi, fiber; nt, non-glandular trichome; pc, phenolic compound; ph, phloem; pi, pith; $x y, x y l e m]$. Scale bar: $a, b=500 \mu m ; d=200 \mu m$; $c, e, f=50 \mu \mathrm{m} ; g=5 \mu \mathrm{m}$. 


\section{DISCUSSION}

It is important to highlight that this is the first report of the micromorphological, histochemical and anatomical characteristics of $M$. hatschbachii. Table 1 shows a summary of the anatomical characteristics of $M$. hatschbachii leaves compared to other species of the genus.

Table 1 - Comparative anatomical characters of leaves of species from genus Myrcia

\begin{tabular}{|c|c|c|c|c|c|c|c|}
\hline & & M. guianensis ${ }^{1 *}$ & M. multiflora* & M. multiflora* & M. decrescens ${ }^{1 *}$ & M. cordiifolia & M. torta ${ }^{1 *}$ \\
\hline $\begin{array}{l}\text { Leaf anatomical } \\
\text { characters }\end{array}$ & M. hatschbachii & $\begin{array}{l}\text { (JORGE et al., } \\
2000)\end{array}$ & $\begin{array}{l}\text { (JORGE et al., } \\
2000)\end{array}$ & $\begin{array}{c}\text { (DONATO; } \\
\text { MORRETES, } \\
\text { 2011) }\end{array}$ & $\begin{array}{l}\text { (GOMES et al., } \\
\text { 2009) }\end{array}$ & $\begin{array}{l}\text { (GOMES et al., } \\
\text { 2009) }\end{array}$ & $\begin{array}{c}\text { (GOMES et al., } \\
\text { 2009) }\end{array}$ \\
\hline Epidermal cell walls & Wavy anticlinal & Wavy anticlinal & $\begin{array}{c}\text { Straight } \\
\text { anticlinal }\end{array}$ & $\begin{array}{c}\text { Straight } \\
\text { anticlinal }\end{array}$ & Wavy anticlinal & Wavy anticlinal & Wavy anticlinal \\
\hline Mesophyll & Dorsiventral & Dorsiventral & Dorsiventral & Dorsiventral & Dorsiventral & Dorsiventral & Dorsiventral \\
\hline Stomata & Paracytic & Ranunculaceous & Ranunculaceous & Paracytic & Paracytic & Paracytic & Paracytic \\
\hline Trichomes & Unicellular & Unicellular & Unicellular & Unicellular & Unicellular & Unicellular & Unicellular \\
\hline \multirow[t]{2}{*}{$\begin{array}{l}\text { Palisade } \\
\text { parenchyma }\end{array}$} & One layer & One layer & Three layers & Three layers & One layer & One layer & Three layers \\
\hline & Secretory cavities & - & - & $\begin{array}{l}\text { Secretory } \\
\text { cavities }\end{array}$ & $\begin{array}{l}\text { Secretory } \\
\text { cavities }\end{array}$ & $\begin{array}{l}\text { Secretory } \\
\text { cavities }\end{array}$ & $\begin{array}{l}\text { Secretory } \\
\text { cavities }\end{array}$ \\
\hline \multirow[t]{2}{*}{ Ground parenchyma } & Starch grains & - & - & Starch grains & - & - & - \\
\hline & Druses** & Druses** & Druses** & Druses** & - & - & - \\
\hline Midrib shape & Concave-convex & Concave-convex & Flat-convex & Concave-convex & Biconvex & Flat-convex & Flat-convex \\
\hline Vascular system & C-shaped & Open arc & Open arc & - & Open arc & Open arc & Open arc \\
\hline
\end{tabular}

Source: Authors (2020)

In where: ${ }^{1}$ Myrcia guianensis (Aubl.) DC. = Myrcia decrescens (O. Berg) Mattos = Myrcia torta DC. *Group: "pedra-hume-caá", "pedra-ume-caá" or "insulin plant" (Cascaes et al., 2015). **Calcium oxalate druses.

Some features found in M. hatschbachii were also observed in other species belong to the genus Myrcia (JORGE et al., 2000; RETAMALES; SCHARASCHKIN, 2015) or the family Myrtaceae (METCALFE; CHALK, 1979; LANDRUM; KAWASAKI, 1997; WILSON, 2011). For instance, in the leaves, wavy anticlinal epidermal cell walls, unicellular non-glandular trichomes, dorsiventral mesophyll and secretory cavities are common characteristics and these features contribute to the taxonomy of the genus and family. 
According to Metcalfe and Chalk (1979), calcium oxalate crystals of various shapes are commonly found in Myrtaceae. Among the most common crystal are druses, which are common in several genera of Myrtaceae, such as Eucalyptus L'Hér, Eugenia, Gomidesia O. Berg, Psidium L., and Myrcia, and other genera from South America (CARDOSO et al., 2009; GOMES et al., 2009; SAULLE et al., 2018; MIGACZ et al., 2018). However, prismatic calcium oxalate crystals are also found in the family (SAULLE et al., 2018; MIGACZ et al., 2018), not only in the mesophyll and ground parenchyma, but also on the epidermis of the leaves (MIGACZ et al., 2018).

Myrcia multiflora contains prismatic crystals in the vascular bundles (DONATO; MORRETES, 2011). Crystals are scarce in M. guianensis (JORGE et al., 2000), whereas they are absent in M. coriacea (SUGDEN, 1985). Although the size and the amount of crystals vary among different taxa, their shape and location within a taxon is usually specific and may be considered as a taxonomic characteristic (FRANCESCHI; NAKATA, 2005). In the present study, several calcium oxalate druses are found in the spongy parenchyma of $M$. hatschbachii. This feature help in the diagnosis of the species.

The midrib of leaves has a concave-convex shape. A slightly concave-convex shape has been observed in M. multiflora (DONATO; MORRETES, 2011), a biconvex shape in M. decrescens, and a flat-convex shape in M. cordiifolia DC. and M. torta DC. (GOMES et al., 2009). The bicollateral vascular system, with a single C-shaped vascular bundle was found in M. hatschbachii and it is common in other species of Myrtaceae family (GOMES et al., 2009; DONATO; MORRETES, 2011). However, M. guianensis, M. multiflora (JORGE et al., 2000), M. cordiifolia, M. decrescens, and M. torta (GOMES et al., 2009) have an open arc vascular system.

Although they present variable forms of the midrib and the vascular system (DONATO; MORRETES, 2011; GOMES et al., 2009; JORGE et al., 2000), the species $M$. multiflora, M. guianensis or $M$. decrescens, and $M$. hatschbachii are native to Brazil and have geographic regions (Santa Catarina and Rio Grande do Sul) and phytogeographic domain (Atlantic Forest) in common (BFG, 2018). Thus, the 
anatomical diagnostic features contribute to the identification of these species and can assist further studies on the possible differentiation from the species of the genus Myrcia, including the insulin plants group, such as M. multiflora.

The vascular system of petiole consists of a bicollateral vascular bundle in an open arch with invaginated ends. Different outline was found in Myrcia multiflora, flat-convex shape with one vascular bundle in an open arc (DONATO; MORRETES, 2011). The shape and the pattern of the vascular system of the midrib and petiole are anatomical markers that can help to the identification of the species, as stated by some authors (WOSCH et al., 2015; BOBEK et al., 2016; BUDEL et al., 2018) and observed in the present study.

Phenolic compounds were found in great amount, through histochemical tests, in leaves, petiole, and stem. These data corroborate the main metabolites found in the family and genus. The family Myrtaceae (RODRIGUES et al., 2016) and the genus Myrcia (CASCAES et al. 2015) are characterized by the presence of phenolic compounds, in addition, the species M. hatschbachii presented a high content of these compounds in in vitro tests (GATTO et al., 2020).

\section{CONCLUSION}

The present study is the first to explore and document the anatomical and histochemical features of $M$. hatschbachii. Although most of the characteristics highlighted in the present study are common in the family Myrtaceae, the following anatomical and histochemical features taken together can help the identification of $M$. hatschbachii: druses in the spongy parenchyma, concave-convex midrib, heart-shaped petiole, oval-shaped stem, and C-shaped vascular bundle in the midrib and open arc shape with invaginated ends in the petiole; phenolic compounds in the phloem and lignified cells in the pith. Studies like this are required to assist informed decisions on the classification and taxonomy of the high diversified genus Myrcia as well as the family Myrtaceae. Further studies that 
integrate anatomical and histochemical characteristics with phylogenetic analysis are essential in understanding the evolution and ecological implications of the traits evidenced.

\section{ACKNOWLEDGMENTS}

This work was carried out with the support of the Coordination of Improvement of Higher Education Personnel - Brazil (CAPES) - Financing Code 001. The authors are grateful to UEPG and c-Labmu for the assistance in the analysis, and to the taxonomist José Tadeu Weidlich Motta for the identification of the species.

\section{REFERENCES}

ALVES MF, NIZIO DAC, SAMPAIO TS, NASCIMENTO JUNIOR AF, BRITO FA, MELO JO, et al. Myrcia lundiana Kiaersk native populations have different essential oil composition and antifungal activity against Lasiodiplodia theobromae. Ind Crops Prod. 2016;85:266-273.

BERLYN GP, MIKSCHE JP. Botanical microtechnique and cytochemistry. Ames: lowa State University Press; 1976.

BFG - The Brazil Flora Group. Brazilian Flora 2020: innovation and collaboration to meet Target 1 of the Global Strategy for Plant Conservation (GSPC). Rodriguésia. 2018;69:1513-1527.

BOBEK VB, HEIDEN G, OLIVEIRA CF, ALMEIDA VP, PAULA JP, FARAGO PV, et al. Comparative analytical micrographs of vassouras (Baccharis, Asteraceae). Rev. Bras. Farmacogn. 2016;26:665-672.

BRITO NR, LANETTI RA. A saúde pelas plantas e ervas do mundo inteiro. Rio de Janeiro: Ed. Ouro; 1996.

BUDEL JM, RAMAN V, MONTEIRO LM, ALMEIDA VP, BOBEK VB, HEIDEN G, et al. Foliar anatomy and microscopy of six Brazilian species of Baccharis (Astereraceae). Microsc Res Tech. 2018;81:832-842.

CASCAES MM, GUILHON GMSP, ANDRADE EHA, ZOGHBI MGB, SANTOS LS. Constituents and pharmacological activities of Myrcia (Myrtaceae): A review of an aromatic and medicinal group of plants. Int. J. Mol. Sci. 2015;10:23881-23904. 
CARDOSO CMV, PROENÇA SL, SAJO MG. Foliar anatomy of the subfamily Myrtoideae (Myrtaceae). Aust. J. Bot. 2009;57:148-161.

DONATO AM, MORRETES BL. Morfo-anatomia foliar de Myrcia multiflora (Lam.) DC. - Myrtaceae. Rev. bras. plantas med. 2011;13:43-51.

FLORA DO BRASIL 2020 [Internet]. Jardim Botânico do Rio de Janeiro. [cited 2020 out 13]. Available from: http://floradobrasil.jbrj.gov.br/reflora/floradobrasil/FB10660.

FOSTER AS. Practical plant anatomy. Princeton: D. Van Nostrand; 1949.

FRANCESCHI VR, NAKATA PA. Calcium oxalate in plants: formation and function. Annu. Rev. Plant Biol. 2005;56:41-71.

FUCHS CH. Fuchsin staining with $\mathrm{NaOH}$ clearing for lignified elements elements of whole plants or plants organs. Stain Technol. 1963;38:141-144.

GABE M. Techniques Histologiques. Paris: Masson \& Cie; 1968.

GATTO LJ, VEIGA A, GRIBNER C, MOURA PF, RECH KS, MURAKAMI FS, DIAS JFG, MIGUEL OG, MIGUEL MD. Myrcia hatschbachii: antifungal activity and structural elucidation of ellagic and 3O-methyl ellagic acids. Nat Prod Res 2020;1-4.

GOMES SM, SOMAVILLA NSDN, GOMES-BEZERRA KM, MIRANDA SC, CARVALHO OS, GRACIANORIBEIRO D. Anatomia foliar de espécies de Myrtaceae: contribuições à taxonomia e filogenia.

Acta bot. bras. 2009;23:223-238.

JOHANSEN DA. Plant Microtechnique. New York: McGraw Hill Book; 1940.

JORGE LIF, AGUIAR JPL, SILVA MLP. Anatomia foliar de pedra hume-caá (Myrcia sphaerocarpa, Myrcia guianensis, Eugenia punicifolia - Myrtaceae). Acta Amaz. 2000;30:49-57.

LANDRUM LR, KAWASAKI ML. The genera of Myrtaceae in Brazil: an illustrated synoptic treatment and identification keys. Brittonia. 1997;49:508-536.

LUCAS EJ, HOLST B, SOBRAL M, MAZINE FF, NIC LUGHADHA E, PROENÇA CEB, COSTA IR, VASCONCELOS TNC. A new tribal classification of tribe Myrteae (Myrtaceae). Syst. Bot. 2019;44:560-569.

LUCAS EJ, MATSUMOTO K, HARRIS AS, LUGHADHA EMN, BENARDINI B, CHASE, MW. Phylogenetics, Morphology, and Evolution of the Large Genus Myrcia s.l. (Myrtaceae). Int. J. Plant Sci. 2011;172:915-934.

METCALFE CR, CHALK L. Anatomy of the Dicotyledons. Oxford: Clarendon Press; 1979. 
MIGACZ IP, RAESKI PA, ALMEIDA VP, RAMAN V, NISGOSKI S, MUNIZ GIB, et al. Comparative leaf morpho-anatomy of six species of Eucalyptus cultivated in Brazil. Rev. Bras. Farmacogn. 2018;28:273-281.

O'BRIEN TP, FEDER N, MCCULLY ME. Polychromatic staining of plant cell walls by toluidine blue O. Protoplasma. 1964;59:368-373.

OLIVEIRA F, AKISUE G. Fundamentos de farmacobotânica. São Paulo: Atheneu; 1997.

RETAMALES HA, SCHARASCHKIN T. Comparative leaf anatomy and micromorphology of the Chilean Myrtaceae: Taxonomic and ecological implications. Flora. 2015;217:138-154.

RODRIGUES MCM, BORGES LL, MARTINS FS, MOURÃO RHV, CONCEIÇÃO EC Optimization of ultrasound-assisted extraction of phenolic compounds from Myrcia amazonica DC. (Myrtaceae) leaves. Pharmacogn. Mag. 2016;12:9-12.

ROESER KR. [The needle of black pine mass-produced and nature's work of art]. Mikrokosmos. 1972;61:33-36. German.

SANTOS MF, SANO PT, FOREST F, LUCAS E. Phylogeny, morphology and circumscription of Myrcia sect. Sympodiomyrcia (Myrcia s.l., Myrtaceae). Taxon 2016;65:759-774.

SASS JE. Botanical Microtechnique. Ames: lowa State College; 1951.

SAULLE CC, RAMAN V, OLIVEIRA AVG, MAIA BHLNS, MENEGHETTI EK, FLORES TB, et al. Anatomy and volatile oil chemistry of Eucalyptus saligna cultivated in South Brazil. Rev. Bras. Farmacogn. 2018;28:125-134.

SUGDEN AM. Leaf anatomy in a Venezuelan Montana forest. Bot. J. Linn. Soc. 1985;90:231-241.

WILSON PG, O'BRIEN MM, HESLEWOOD MM, QUINN CJ. Relationships within Myrtaceae sensu lato based on a matK phylogeny. Plant Syst. Evol. 2005;251:3-19.

WILSON P. Myrtaceae. In: Kubitzki, K. (eds.). The families and genera of vascular plants. Flowering plants Eudicots: Sapindales, Cucurbitales, Myrtaceae. Heidelberg: Springer-Verlag; 2011.

WOSCH L, IMIG DC, CERVI AC, MOURA BB, BUDEL JM, SANTOS CAM. Comparative study of Passiflora taxa leaves: I. A morpho-anatomic profile. Rev. Bras. Farmacogn. 2015;25:328-343.

\section{Authorship contributions}

\section{1 - Larissa Junqueira Gatto}

PhD in Pharmaceutical Sciences

http://orcid.org/0000-0001-6451-7445 - lari.gatto@gmail.com

Contribuition: Conceptualization, Methodology, Writing - original draft 


\section{2 - Vanessa Barbosa Bobek}

PhD in Pharmaceutical Sciences

http://orcid.org/0000-0002-2836-2076 - vanessabbobek@gmail.com

Contribuition: Methodology, Writing - original draft

\section{3 - Jane Manfron Budel}

PhD in Pharmaceutical Sciences, Professor of the Department of Sciences

Pharmaceuticals

http://orcid.org/0000-0003-1873-2253 - janemanfron@hotmail.com

Contribution Writing - review \& editing

\section{4 - Natasha Tiemi Fabri}

Master in Pharmaceutical Sciences

http://orcid.org/0000-0003-4237-7626 - natasha.fabri@gmail.com

Contribuition: Methodology

\section{5 - Josiane de Fatima Gaspari Dias}

PhD in Pharmaceutical Sciences, Professor of the Department of Pharmacy

http://orcid.org/0000-0002-8548-8505 - josianefgdias@gmail.com

Contribuition: Methodology

\section{6 - Obdulio Gomes Miguel}

$\mathrm{PhD}$ in Chemistry, Professor at the Department of Pharmacy

http://orcid.org/0000-0002-2231-9130 - obdulio@ufpr.br

Contribuition: Supervision

\section{7 - Marilis Dallarmi Miguel}

PhD in Agronomy, Professor at the Department of Pharmacy

http://orcid.org/0000-0002-1126-921 - marilisdmiguel@gmail.com

Contribuition: Supervision

\section{How to quote this article}

GATTO, L. J.; et al. Contribution to the identification of the species Myrcia hatschbachii D. Legrand (Myrtaceae): anatomical and histochemical analyses. Ciência e Natura, Santa Maria, v. 43, e75, p. 1-18, 2021. Available at: https://doi.org/10.5902/2179460X43417. 